Article

\title{
Causality between Stock Prices and Exchange Rates in Turkey: Empirical Evidence from the ARDL Bounds Test and a Combined Cointegration Approach
}

\author{
Turgut Türsoy \\ Department of Banking and Finance, Near East University, Near East Boulevard, 99138 Nicosia, North Cyprus, \\ Mersin 10 Turkey; turgut.tursoy@neu.edu.tr; Tel.: +90-392-675-1000-3118 \\ Academic Editor: Nicholas Apergis \\ Received: 6 September 2016; Accepted: 10 February 2017; Published: 1 March 2017
}

\begin{abstract}
This paper investigates the interaction between stock prices and real exchange rates by applying monthly data from Turkey for the period between January 2001 and September 2016. This study uses the autoregressive distributed lag (ARDL) model and the Error Correction Model (ECM) in order to investigate the existence of a long-run equilibrium relationship between the variables. The evidence reveals that there is a strong long-run cointegration. The robustness of the ARDL bounds test cointegration was confirmed using the newly-developed combined cointegration, which also provided the same evidence for a strong long-run relationship. The Granger causality test results indicate a long-run bidirectional causality between stock prices and real exchange rates, and also a unidirectional causality from the real exchange rates to the stock prices in the short-run. In order to analyze the validity and reliability of the test results, diagnostic tests were applied in both the short-run and long-run models.
\end{abstract}

Keywords: real exchange rate; stock prices; ARDL bounds test; combined cointegration

JEL Classification: F31; F41; G12; G15

\section{Introduction}

Recent changes in global stock markets, such as the vast financial integration between countries' financial markets and the increasing prevalence of countries opting to accept more flexible exchange rates, have increased the interest in studying the interactions between stocks and foreign exchange markets. In particular, the relaxation of restrictions or controls on private capital accounts has increased international investments, as well as portfolio diversification opportunities for countries. At the same time, the adoption of more flexible exchange rate regimes by countries has increased the volatility of the foreign exchange markets and the risks associated with international investments. In general, in all international portfolio investments, the choice of the currency denomination is a decisive factor. Therefore, the choice of both currency and portfolio investment decisions is important, as it is expected that they will have an effect on each other. Additionally, movements into funds at the international level, caused by stock market changes, may have affected the value of the exchange rates. Changes in local stock markets, caused by events that occur in other countries or in the international market, as well as the interaction between exchange rates, merit close attention because the markets are more open to international investment and the exchange rate regimes are floating. 
A significant amount of literature ${ }^{1}$ has focused on dynamic models by emphasizing modern time series procedures, such as cointegration, and vector autoregressive (VAR) and causality models. The majority of existing empirical studies have analyzed the relationship between stock prices and exchange rates, and illustrate different results between countries caused by model specifications, as well as differences in the data and periods analyzed. For example, there have been empirical studies $^{2}$ that have applied recent developments in cointegration analysis with structural breaks in order to analyze the relationship between variables. For instance, Granger et al. (2000) [8] applied the Zivot and Andrews (1992) [11] unit root and the Gregory and Hansen (1996) [12] cointegration models in order to determine the appropriate Granger relations between stock prices and exchange rates.

Recent studies in Turkey on the long- and short-run relationships between stock prices and exchange rates include contributions by Bahmani-Oskooee and Domac (1997) [13], Kasman (2003) [14], Sevuktekin and Nargelecekenler (2007) [15], Pekkaya and Bayramoglu (2008) [16], Aydemir and Demirhan (2009) [17], and Rjoub (2012) [18]. These studies include analyses using cointegration and Granger causality tests, and the majority of them reported long-run relationships with both bidirectional and unidirectional causations.

The purpose of this study is to explore whether there are long- and short-run relationships between the stock prices and real exchange rates in Turkey. The research methodology consists of conducting newly-developed cointegration tests, based on Pesaran et al. (2001) [19] and Bayer and Hanck (2013) [20], and the Error Correction Model (ECM) Granger causality. The autoregressive distributed lag (ARDL) bounds test of cointegration is used to investigate the long-run relationship, and the ARDL framework is applied to analyze the long-run and short-run dynamics. Additionally, Bayer and Hanck's (2013) [20] combined cointegration technique is employed to verify the robustness of the model. In this study, the direction of causality is applied differently in the forms of short-run (weak causality), long-run, and joint (short-run and long-run together-strong causality). Moreover, Turkey abandoned the fixed exchange rate regime at the beginning of 2001 and officially transferred to the floating exchange rate regime. This highlights the importance of analyzing the interaction between stock prices and exchange rates for the period between February 2001 and September 2016 in order to account for the effects of the flexible exchange rate regime. The remainder of the article is organized as follows. Section 2 explains the theoretical background. Sections 3 and 4 explain the model and the data. Section 5 elucidates the econometric methodology. Section 6 provides the empirical results and discussion. Finally, Section 7 concludes the article.

\section{Theoretical Background}

Based on economic theory, there are two possible channels through which stock prices and exchange rates can interact. The first channel is based on the relationship between the real exchange rate and economic activity (flow-oriented model) ${ }^{3}$. Appreciations or depreciations in the domestic currency of a country affect the international competitiveness of domestic goods and, consequently, affect the current account position. This directly affects the real output of the country and as a result, the current and future cash flows of companies. For example, a fall in the real exchange rate increases the competitiveness of domestic goods versus foreign goods, as well as the level of domestic aggregate demand and output. Since the stock price of a firm reflects expected future cash flows, it can be influenced by future internal and external aggregate demand. Hence, the stock prices incorporate current and expected economic activity, as measured by industrial production, real economic growth, employment rates, or corporate profits.

1 Some of the studies are Aggarwal (1981) [1], Bahmani-Oskooee and Sohrabian (1992) [2], Ajani and Mougoue (1996) [3], Abdalla and Murinde (1997) [4], Nieh and Lee (2001) [5], Kim (2003) [6], and Phylaktis and Ravazzolo (2005) [7].

For example, Granger et al. (2000) [8], Kasman and Ayhan (2008) [9], Chaban (2010) [10].

See Dornbush and Fisher (1980) [21]. 
The second possible channel depends on the portfolio approach to exchange rate determination (Gavin (1989) [22]). According to this model, agents allocate their wealth into various assets, such as domestic money, domestic securities, and foreign securities. The role of the exchange rate is to balance the asset demands and supplies. Thus, any change in the demand for, and supply of, assets changes the equilibrium exchange rate. For example, an increase in any country's stock market will cause another stock market to rise as a result of the greater integration between the domestic and international markets; which, in turn, will increase the demand for assets. The excess demand for money will increase interest rates and a substitution from foreign securities to domestic securities will result in an appreciation of the domestic currency and a rise in the real exchange rate.

In particular, Aggarwal (1981) [1] has argued that stock prices can be influenced in a variety of ways by exchange rates, whether a company is multinational or not. Theoretically, there are two approaches (traditional and portfolio), as mentioned above, that explain the connection between stock prices and exchange rates. However, the direction of causation differs in the two approaches. In the traditional approach, exchange rate changes usually lead to changes in stock prices, and in the portfolio approach, the reverse is true.

\section{Data}

A bivariate framework is applied in order to investigate the relationship between stock prices and real exchange rates. All the monthly data are collected from the International Financial Statistics (IFS) [23] for the period between February 2001 and September 2016.

\section{Model}

The role of the nominal exchange rate is to measure the value of one currency relative to another (Daniels and Vanhoose, 2005 [24] (p. 38)). Essentially, the real exchange rate removes the effects of changes in a nations' price level from the nominal exchange rate. In this way, it is possible to calculate the real exchange rate ${ }^{4}$, as shown below:

$$
s_{t}=S_{t} \times\left(P_{t}^{U S} / P_{t}^{T L}\right)
$$

where $S_{t}$ denotes the nominal Turkish-Lira-per-U.S.-dollar exchange rate, $T L / \$$, at time period $t$; $P_{t}^{U S}$ denotes the U.S. Consumer Price Index (CPI) at time period $t$ and $P_{t}^{T L}$ denotes the Turkish CPI at time period $t$. Using these notations, the real Turkish-Lira-per-U.S.-dollar exchange rate at time period $t$, is defined as $s_{t}$, and is calculated using Equation (1).

The purpose of this study is to investigate the relationship between the real exchange rates (RealExc), which is calculated by Equation (1), and the stock prices $(I E Q)$. The following Equations (2) and (3) represent the relationship between the variables.

$$
\begin{aligned}
& l E Q_{t}=\beta_{0}+\beta \text { Real Exc } c_{t}+\varepsilon_{t} \\
& \text { Real Exc } c_{t}=\beta_{0}+\beta L E Q_{t}+\varepsilon_{t}
\end{aligned}
$$

where $l E Q_{t}$ is the stock price (equity price, index), and Real Exct is the real exchange rate.

\section{Methodology}

\subsection{Unit Root Test}

The general focus of researchers in the field of finance is to obtain unbiased test results from empirical studies in order to determine an equilibrium relationship between variables. In particular,

4 This study uses the real exchange rate calculation method of Daniels and Vanhoose (2005) [24] (p. 43). 
the traditional unit root could be biased when there is a structural break in a time series. Thus, empirical evidence provided by previous studies has highlighted the importance of testing breaks when investigating the order of integration. For instance, Perron (1989) [25] proposed a unit root test allowing for a structural break. Based on the explanations mentioned previously, this paper applies two kinds of unit root tests, namely the Perron and Vogelsang (1992) [26] and the Clemente et al. (1998) [27] unit root tests. In the Perron and Vogelsang (1992) [26] unit root test, only one structural break is considered in the series to determine the correct order of integration. There are two forms in this unit root test, which are the additive outlier (AO) model and the innovative outlier (IO) model, which capture the immediate and gradual shocks, respectively. The Clemente et al. (1998) [27] unit root test, additionally, tests for two structural breaks. In the same manner as Perron and Vogelsang (1992) [26], the Clemente et al. (1998) [27] unit root test has two forms: AO, allowing for sudden changes in mean, and IO models, allowing for gradual changes.

\subsection{ARDL Bounds Test of Cointegration}

In this study, the Autoregressive Distributed Lag (ARDL) bounds test, which was developed by Pesaran et al. (2001) [19], is used to determine the cointegration between the variables. In order to estimate the cointegration, the ARDL framework presents various advantages. For example, the ARDL model can apply to different orders of integration for the variables. The dependent variable should be $I(1)$; however, the other variables can be either $I(0)$ and $I(1)$ or a mixed order of integration. The first step in cointegration analysis is to verify the order of integration by applying the unit root tests. The ARDL model for stock prices and real exchange rates is as follows:

$$
\begin{gathered}
\Delta \ln E Q_{t}=\beta_{0}+\sum_{i=1}^{p} \beta_{1 i} \Delta \ln E Q_{t-i}+\sum_{i=0}^{q} \beta_{2 i} \Delta \operatorname{RealExc}_{t-i}+\lambda_{1 i} \ln E Q_{t-1}+\lambda_{2 i} \operatorname{RealExc}_{t-1}+v_{1 t}, \\
\Delta \text { RealExc }{ }_{t}=\beta_{0}+\sum_{i=0}^{q} \beta_{2 i} \Delta \text { RealExc } c_{t-i}+\sum_{i=1}^{p} \beta_{1 i} \Delta \ln E Q_{t-i}+\lambda_{1 i} \operatorname{RealExc}_{t-1}+\lambda_{2 i} \ln E Q_{t-1}+v_{1 t},
\end{gathered}
$$

where $v_{1 t}$ is the error term that should be white noise and $\Delta$ shows the first difference operator. The Akaike Information Criterion (AIC) was used for the lag length selection. In the ARDL bounds test of cointegration, both $F$-statistics and Wald tests are used to examine the null hypothesis of no cointegration among the variables. In the ARDL bounds test, the estimated F-statistics value is compared with the two sets of critical values of the upper- and lower-bounds. If the estimated $F$-statistics value is higher than the upper- and lower-bound critical values, then the null hypothesis of no cointegration is rejected. If it lies between the two critical values, the conclusion is indecisive. If the F-statistics value is lower that the critical values, the null hypothesis of no cointegration is accepted. After the bounds test confirms the cointegration between the variables, the long-run (Equations (6) and (7)) and short-run (Equations (8) and (9)) coefficients can be investigated.

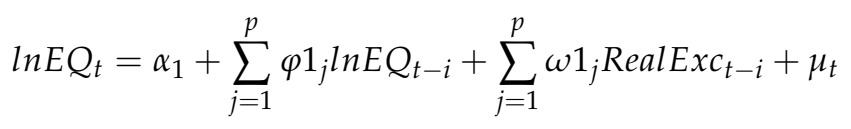

$$
\begin{aligned}
& \operatorname{RealExc_{t}}=\alpha_{1}+\sum_{j=1}^{p} \varphi 1_{j} \operatorname{RealExc}_{t-i}+\sum_{j=1}^{p} \omega 1_{j} \ln E Q_{t-i}+\mu_{t} \\
& \Delta \ln E Q_{t}=\gamma_{0}+\sum_{j=1}^{p 1} \gamma_{1 i} \Delta \ln E Q_{t-i}+\sum_{j=1}^{p 2} \gamma_{2 i} \Delta \operatorname{RealExc}_{t-i}++\psi E C T_{t-1}+\vartheta t \\
& \Delta \operatorname{RealExC}_{t}=\gamma_{0}+\sum_{j=1}^{p 1} \gamma_{1 i} \Delta \operatorname{RealExC}_{t-i}+\sum_{j=1}^{p 2} \gamma_{2 i} \Delta \ln E Q_{t-i}++\psi E C T_{t-1}+\vartheta t,
\end{aligned}
$$


In Equations (8) and (9), $E C T_{t-1}$ represents the error correction term. In general, the $E C T_{t-1}$ should be negative and between $0-1$. Usually, the $E C T_{t-1}$ reports the speed of the adjustment to converge back to its long-run equilibrium.

The robustness of the ARDL bounds test of cointegration results are compared with the Bayer and Hanck (2013) [20] combined cointegration. Bayer and Hanck (2013) [20] provided a new framework to verify cointegration between the variables by combining the Engle and Granger (1987) [28], Johansen (1988) [29], Boswijk (1994) [30], and Banerjee et al. (1998) [31] cointegration methods. The Bayer and Hanck combined cointegration technique generates a joint $t$-statistic based on four cointegration methods. This combined method improves the power of cointegration and provides more conclusive results by combining the four individual cointegration tests. The equations below show the Fisher equation of Bayer and Hanck (2013) [20]:

$$
\begin{gathered}
E G-J O H=-2\left[\left(\text { Pro }_{\mathrm{EG}}\right)+\left(\text { Pro }_{\mathrm{JOH}}\right)\right] \\
E G-J O H-B O S-B A N=-2\left[\left(\text { Pro }_{\mathrm{EG}}\right)+\left(\text { Pro }_{\mathrm{BOS}}\right)+\left(\text { Pro }_{\mathrm{BAN}}\right)+\left(\text { Pro }_{\mathrm{JOH}}\right)\right]
\end{gathered}
$$

\subsection{Causality Analysis}

After confirming the long-run relationship between stock prices and real exchange rates by applying the ARDL bounds test and combined cointegration techniques, the Granger causality can be applied to investigate the direction of causality among the variables. The Error Correction Model (ECM) based Granger causality test is applied to investigate the direction of causality between the variables.

$$
\begin{gathered}
\Delta \ln E Q=\delta_{0}+\sum_{i=1}^{p} \lambda_{1 i} \Delta \ln E Q_{t-1}+\sum_{i=1}^{q} \lambda_{1 i} \Delta \text { RealExc }_{t-1}+\varphi_{1} E C_{t-1}+e_{1 t} \\
\Delta \text { RealExc }=\delta_{0}+\sum_{i=1}^{q} \lambda_{2 i} \Delta \text { RealExc }_{t-1}+\sum_{i=1}^{p} \lambda_{2 i} \Delta \ln E Q_{t-1}+\varphi_{2} E C T_{t-1}+e_{2 t}
\end{gathered}
$$

where $E C T_{t-1}$ presents the lagged error correction term and $\Delta$ represents the first difference to examine the short-run dynamic. Additionally, $e_{1 t}$ and $e_{2 t}$ represent the error terms and they should be white noise and serially uncorrelated. The ECM is an important model that distinguishes the short- and long-run Granger causalities. The lag of the individual coefficients is utilized to test the significance of the short-run relationship. Furthermore, the coefficient of $E C T_{t-1}$ is statistically significant and indicates long-run causality. Jointly-lagged coefficients and the ECT are used to verify joint causality between the variables.

\section{Empirical Results}

\subsection{Unit Root Test}

In this Section, the first analysis is the unit root test for determining the order of integration. This study uses the Perron-Vogelsang (1992) [26] and Clemente-Montañés-Reyes (1998) [27] unit root tests. Tables 1 and 2 illustrate the results of these unit root tests. 
Table 1. Perron-Vogelsang test with one endogenous structural break.

\begin{tabular}{|c|c|c|c|c|c|}
\hline Variables & Perro & Vogelsang Tes & vith One Endo & ous Structu & eak \\
\hline \multirow{2}{*}{ Level } & AO-model & \multirow{2}{*}{ TB1 } & IO-model & \multirow{2}{*}{ TB1 } & \multirow{2}{*}{ Result } \\
\hline & $t$-Statistics & & $t$-Statistics & & \\
\hline Real Exc & $-3.504(1)$ & June 2003 & $-3.732(1)$ & Feb 2003 & $I(0)$ \\
\hline $\operatorname{LnEQ}$ & $-3.038(1)$ & March 2005 & $-3.141(1)$ & Feb 2009 & $I(0)$ \\
\hline \multicolumn{6}{|l|}{ First Difference } \\
\hline DReal Eexc & $-9.661 *(1)$ & Aug 2008 & $-12.690 *(1)$ & Sep 2008 & $I(1)$ \\
\hline$D \operatorname{Ln} E Q$ & $-10.539 *(1)$ & Apr 2006 & $-10.450 *(1)$ & May 2006 & $I(1)$ \\
\hline
\end{tabular}

Note: * represents significance at $1 \%$ level.

Table 2. Unit root test with two endogenous structural breaks: Clemente-Montañés-Reyes test.

\begin{tabular}{|c|c|c|c|c|c|c|c|}
\hline Variables & Unit Roo & est With Th & Endogenous & actural Breaks & Clemente-M & tañés-Rey & Test \\
\hline \multirow{2}{*}{ Level } & AO-model & \multirow{2}{*}{ TB1 } & \multirow{2}{*}{ TB2 } & IO-model & \multirow{2}{*}{ TB1 } & \multirow{2}{*}{ TB2 } & \multirow{2}{*}{ Result } \\
\hline & $t$-Statistics & & & $t$-Statistics & & & \\
\hline Real Exc & $-1.200(1)$ & June 2003 & March 2006 & $-3.823(1)$ & Feb 2003 & May 2006 & $I(0)$ \\
\hline $\operatorname{LnEQ}$ & $-4.612(1)$ & Mar 2005 & May 2010 & $-5.212(1)$ & Jun 2003 & Feb 2009 & $I(0)$ \\
\hline \multicolumn{8}{|c|}{ First Difference } \\
\hline DReal Exc & $-7.944 *(1)$ & Mar 2006 & Aug 2008 & $-13.027 *(1)$ & Apr 2003 & Sep 2008 & $I(1)$ \\
\hline$D L n E Q$ & $-11.149 *(1)$ & Oct 2007 & Jan 2009 & $-11.044 *(1)$ & Nov 2007 & Feb 2009 & $I(1)$ \\
\hline
\end{tabular}

Note: ${ }^{*}$ represents the significance at $1 \%$ level.

The Perron-Vogelsang (1992) [26] unit root test allows for one structural break and the Clemente-Montañés-Reyes (1998) [27] unit root test considers two structural breaks in the series. Both of these unit root tests provide two models: An additive outliers (AO) model, which considers a sudden change, and an innovative outliers (IO) model, which considers a gradual shift in the series. Both the Perron-Vogelsang and Clemente-Montañés-Reyes test results are reported in Tables 1 and 2, respectively. Both tables provide test results demonstrating that all variables are nonstationary at level and stationary by taking the first difference.

\subsection{Cointegration Results}

After verifying the unit root properties of the variables, the bounds test of cointegration can be implemented for Equations (4) and (5) in order to analyze the long-run relationship between the variables. Table 3 reports the estimated F-statistics values for the models. The second row in Table 3 represents the optimal lag length for the models, which was selected via the AIC criterion. The table provides evidence for cointegration and a long-run relationship between the two variables. For instance, the estimated F-statistics value for the model of $F_{L E Q}(L E Q /$ Real Exc) is 4.82, which is above the upper bound critical values provided by Pesaran et al. (2001) [19] at 10\%. For the second model of $F_{\text {Real Exc }}($ Real Exc/LEQ), the estimated F-statistics value is 5.59 and it lies above the upper bound critical values at $5 \%$.

For analyzing the long-run relationship, Equations (6) and (7) were applied, whereas for the short-run analysis, Equations (8) and (9) were applied. The long-run coefficients and error correction terms are reported in Tables 4 and 5. The long-run coefficient for the real exchange rates is negative and significant at $1 \%$, which is observed in Table 4 . Additionally, the coefficient of the error correction term (ECT) is $9.05 \%$, and this represents the speed of the adjustment. The ECT is negative and statistically significant at $1 \%$. Therefore, this implies that the stock prices converge to the long-run equilibrium by $9.05 \%$ in one period with the speed adjustment via the channel of real exchange rates. 
Table 3. Results of the bounds test of cointegration.

\begin{tabular}{|c|c|c|c|c|}
\hline Estimated Model & \multicolumn{2}{|c|}{$F_{L E Q}(L E Q / R e a l$ Exc $)$} & \multicolumn{2}{|c|}{$F_{\text {Real Exc }}($ Real Exc/LEQ $)$} \\
\hline Optimal Lag Length (AIC) & \multicolumn{2}{|c|}{$(6,6)$} & \multicolumn{2}{|c|}{$(6,6)$} \\
\hline F-Statistics (Bound Test) ${ }^{5}$ & \multicolumn{2}{|c|}{$4.82^{* * *}$} & \multicolumn{2}{|c|}{$5.59 * *$} \\
\hline Critical Values & $1 \%$ & $2.5 \%$ & $5 \%$ & $10 \%$ \\
\hline Lower Bounds $I(0)$ & 6.1 & 5.3 & 4.68 & 4.05 \\
\hline Upper Bounds I(1) & 6.73 & 5.83 & 5.15 & 4.49 \\
\hline$R^{2}$ & \multicolumn{2}{|c|}{0.43} & \multicolumn{2}{|c|}{0.42} \\
\hline Adj. $R^{2}$ & \multicolumn{2}{|c|}{0.39} & \multicolumn{2}{|c|}{0.37} \\
\hline F-Statistics & \multicolumn{2}{|c|}{$9.3281 *$} & \multicolumn{2}{|c|}{8.8043 * } \\
\hline
\end{tabular}

Note: ${ }^{*}{ }^{* *}$, and ${ }^{* * *}$ represents significance at the $1 \%, 5 \%$, and $10 \%$ levels, respectively. The Akaike Information Criterion (AIC) criterion is used to determine the optimal lag. The critical values are determined from Pesaran et al. (2001) [19].

Table 4. Autoregressive Distributed Lag (ARDL) long-run results with the error correction term.

\begin{tabular}{cccc}
\hline \multicolumn{4}{c}{ Dependent Variable: LEQ } \\
\hline \multicolumn{4}{c}{ Long-Run Results } \\
\hline Variable & Coefficient & Standard Error & $t$-Statistics \\
\hline Real Exc & -0.6067 & 0.1290 & $-4.7015^{*}$ \\
Trend & 0.0091 & 0.0011 & $7.7772^{*}$ \\
$E C T_{t-1}$ & -0.0905 & 0.0236 & $-3.8279 *$ \\
$R^{2}$ & 0.993 & S.E of regression. & 0.0585 \\
Adj. $R^{2}$ & 0.992 & Sum Squared resid & 0.5726 \\
F-Statistics & $1738.62 *$ & DW & 1.99 \\
\hline
\end{tabular}

Note: ${ }^{*}$ represents significance at the $1 \%$ level. DW represent Durbin Watson test statistics.

Table 5. ARDL long-run results with error correction term.

\begin{tabular}{cccc}
\hline \multicolumn{4}{c}{ Dependent Variable: Real Exc } \\
\hline \multicolumn{4}{c}{ Long-Run Results } \\
\hline Variable & Coefficient & Standard Error & $t$-Statistics \\
\hline LEQ & -0.9582 & 0.3416 & $-2.8052^{*}$ \\
Trend & 0.0103 & 0.0043 & $2.3573^{*}$ \\
$E C T_{t-1}$ & -0.0687 & 0.0166 & $-4.1230^{*}$ \\
$R^{2}$ & 0.975 & S.E of regression. & 0.0773 \\
Adj. $R^{2}$ & 0.972 & Sum Squared resid & 0.9988 \\
F-Statistics & $466.2473^{*}$ & DW & 1.99 \\
\hline
\end{tabular}

Note: * represents significance at the $1 \%$ level.

The long-run coefficient of the stock prices is also negative and statistically significant in the ARDL long-run equation (Table 5). The coefficient of ECT is $6.87 \%$ and is statistically significant, even at $1 \%$. This result reveals that the real exchange rate converges on its long-run equilibrium by $6.87 \%$ with the speed adjustment via the channel of stock prices.

The estimations are also examined via all diagnostic tests for the short- and long-runs, and the results are reported in Table 6. The diagnostic test results show that all the estimations pass all diagnostic tests and verify each of the basic assumptions of a classical linear regression model.

5 The ARDL model is estimated by using an un-restricted intercept and trend (Case IV). 
Table 6. Long-run and short-run diagnostic tests for models.

\begin{tabular}{cccccc}
\hline Diagnostic Test & $\chi^{2} \mathbf{s c}$ & $\chi^{2} \mathbf{H}$ & $\chi^{2} \mathbf{N}$ & $\chi^{2} \mathbf{A R}$ & $\begin{array}{c}\text { Ramsey Reset Test } \\
(\boldsymbol{F} \text {-Statistics) }\end{array}$ \\
\hline Model 6 (long-run) & $0.0489(0.9758)$ & $21.2246(0.0960)$ & $4.3547(0.1133)$ & $0.0012(0.9971)$ & $0.0399(0.8418)$ \\
\hline Model 7 (long-run) & $0.0023(0.9611)$ & $47.2266(0.001)$ & $34.2710(0.0004)$ & $10.3749(0.9997)$ & $1.0662(0.3033)$ \\
\hline Model 8 (short-run) & $0.0476(0.9765)$ & $11.0124(0.5279)$ & $4.3541(0.1133)$ & $0.0168(0.9967)$ & $0.5868(0.4447)$ \\
\hline Model 9 (short-run) & $0.0021(0.9629)$ & $17.1184(0.1044)$ & $34.2064(0.000)$ & $16.2291(0.0933)$ & $2.1031(0.1489)$ \\
\hline
\end{tabular}

Note: Sc, H, N, AR represent Serial Correlation, Heteroscedasticity, Normality, ARCH tests results, respectively.

The robustness of the ARDL bounds test was investigated using the newly-developed Bayer-Hanck (2013) [20] combined cointegration, which consists of the joint tests of Engle and Granger (1987) [28], Johansen (1988) [29], Boswijk (1994) [30], and Banerjee et al. (1998) [31], respectively. The combined cointegration results are reported in Table 7 . The cointegration result shows evidence of cointegration with the computed $F$-statistics value. The $F$-statistics values for both Engle-Granger and Johansen $(E G-J O H)$ and Engle-Granger, Johansen, Banerjee-Dolado-Mestre and Boswijk (EG-JOH-BAN-BOS) are higher than the critical values of $1 \%$ and this indicates that the null hypothesis of no-cointegration is rejected. This corroborates the previous results provided by the ARDL bounds test cointegration. The combined cointegration results and the critical values are reported in Table 7.

Table 7. Bayer-Hanck cointegration test results.

\begin{tabular}{cccc}
\hline Model Specification & Fisher Statistics & Fisher Statistics & Cointegration Decision \\
\hline & $E G-J O H$ & $E G-J O H-B A N-B O S$ & \\
\hline$F_{L E Q}=f(l e q$, RealExc $)$ & $55.3627^{*}$ & $57.0184^{*}$ & Yes \\
$F_{\text {RealExc }}^{*} f($ RealExc,leq $)$ & $58.4531^{*}$ & $82.4062^{*}$ & Yes \\
\hline Significance Level & Critical Values & & Critical Values \\
\hline Significance level at 1\% & 17.304 & & 33.969 \\
Significance level at 5\% & 11.229 & 21.931 \\
Significance level at 10\% & 8.678 & 16.964 \\
\hline
\end{tabular}

\subsection{Granger Causality}

The Granger Causality test was performed under the error correction model. First, the variables were estimated at level without taking first difference in the unrestricted VAR framework. The lag length was selected using the Akaike information criterion (AIC). The unrestricted VAR model was applied with seventh lag and found an absence of serial correlation. Three types of Granger causalities were applied to find the causality: (1) Short-run causality-the Wald test was applied for all the lag independent variables using the joint $F$ test; (2) long-run causality-investigated by verifying the coefficient of the error correction term (it should be between 0 and 1 with a negative sign), which implies convergence of the system back to the long-run equilibrium position, which is satisfied in Equations (8) and (9); (3) joint (short-run and long-run) causality-the Wald test was applied to both the lagged independent variables and the error correction term using the joint $\mathrm{F}$ test.

Based on the findings in Table 8, real exchange rates "Granger-cause" stock prices in the form of a short-run causality, but stock prices do not "Granger-cause" the real exchange rates. However, based on long-run causality, the coefficients of the lagged error correction terms are negative and significant, and this confirms that a long-run relationship exists between the variables, as verified by the ARDL bounds test. The error correction terms provide evidence for a bidirectional causality between the variables. In the long-run, the real exchange rate "Granger-causes" stock prices and the ECT is -0.0087 . The error correction coefficient provides evidence for the speed of adjustment and that the long-run 
equilibrium between the real exchange rate and stock prices converges back to its position by less than $1 \%$ for one period. Additionally, in the long-run, stock prices "Granger-cause" the real exchange rate, and the ECT is -0.0549 and is statistically significant at $1 \%$. The speed of adjustment for the long-run equilibrium is approximately $5.5 \%$ in one period. Moreover, a joint (short-run and long-run) causality also exists between the real exchange rate and stock prices, a result that confirms the bidirectional causality between the variables.

Table 8. Results of Granger causality.

\begin{tabular}{cccccc}
\hline \multirow{2}{*}{$\begin{array}{c}\text { Dependent } \\
\text { Variable }\end{array}$} & $\begin{array}{c}F \text {-Statistics (Probability) } \\
\text { (Short-Run) }\end{array}$ & \multicolumn{2}{c}{$\begin{array}{c}\text {-Statistics } \\
\text { (Long-Run) }\end{array}$} & \multicolumn{2}{c}{ Joint (Short- and Long-Run) } \\
\cline { 2 - 6 } & $\Delta L E Q$ & $\Delta$ Real Exc & LEQ $_{t-1}($ t-Statistics) & $\Delta$ LEQ.EC $C_{t-1}$ & $\Delta$ Real Exc.EC $C_{t-1}$ \\
\hline$\Delta L E Q$ & & $2.3541^{*}(0.0257)$ & $-0.0087[-2.5602]^{*}$ & & $2.6376^{*}(0.0096)$ \\
$\Delta$ Real Exc & $1.1837(0.3148)$ & & $-0.0549[-5.6377]^{*}$ & $4.8921^{*}(0.0000)$ & \\
\hline
\end{tabular}

Note: * represents the significance level at $1 \%$.

\section{Conclusions}

In Turkey in the early 1980s, the barriers to capital movement were gradually removed and by the beginning of 2001, a floating exchange rate system was introduced by the Turkish authorities. For this reason, the role of the portfolio approach began to increase its level of importance in the Turkish market. Capital flows to the Turkish economy were beneficial, for instance, to finance its current account deficit. Subsequently, Turkey adopted the floating exchange rate system after the economic crisis in 2001. This created an incentive to re-investigate the interaction between the stock market and exchange rates. Therefore, this paper has primarily sought to explain the long-run and short-run relationships between stock prices and exchange rates. In this paper, recently-developed statistical techniques, namely the ARDL bounds test of cointegration and the combined cointegration technique, were applied to analyze the relationship between stock prices and exchange rates in the Turkish market. The results of the Granger causality analyses revealed that the market was characterized by the phenomenon of the traditional approach in the short-run. The market demonstrated that changes in the real exchange rate lead to changes in the stock prices in the short-run. Nonetheless, in the long-run and joint (short-run and long-run) conditions, the Granger causality test results confirm a bidirectional causality between the variables. Therefore, these results in the long-run and joint conditions revealed that both approaches (traditional and portfolio) are acceptable to explain the changes in stock prices and real exchange rates.

Acknowledgments: I wish to thank two anonymous referees for valuable comments and suggestions that have improved substantially the quality of my paper.

Conflicts of Interest: The author declares no conflict of interest.

\section{References}

1. Aggarwal, R. Exchange rates and stock prices: A study of the US capital markets under floating exchange rates. Akron Bus. Econ. Rev. 1981, 12, 7-12.

2. Bahmani-Oskooee, M.; Sohrabian, A. Stock price and the effective exchange rate of dollar. Appl. Econ. 1992, 24, 459-464. [CrossRef]

3. Ajani, R.A.; Mougoue, M. On the dynamic relation between stock prices and exchange rates. Akron Bus. Econ. Rev. 1996, 12, 7-12.

4. Abdalla, I.S.A.; Murinde, V. Exchange rates and stock prices interactions in emerging financial markets: Evidence on India, Korea and Philippines. Appl. Financ. Econ. 1997, 7, 25-35. [CrossRef]

5. Nieh, C.C.; Lee, C.F. Dynamic relationship between stock prices and exchange rates for G-7 Countries. Q. Rev. Econ. Financ. 2001, 41, 477-490. [CrossRef] 
6. Kim, K. Dollar exchange rate and stock price: Evidence from multivariate cointegration and error correction model. Rev. Financ. Econ. 2003, 12, 301-313. [CrossRef]

7. Phylaktis, K.; Ravazzolo, F. Stock price and Exchange rate dynamics. J. Int. Money Financ. 2005, 24, 1031-1053. [CrossRef]

8. Granger, C.W.J.; Huang, B.; Yang, C. A bivariate causality between stock prices and exchange rates: Evidence from recent Asian flu. Q. Rev. Econ. Financ. 2000, 40, 337-354. [CrossRef]

9. Kasman, A.; Ayhan, D. Foreign exchange reserves and exchange rates in Turkey: Structural breaks, unit roots and cointegration. Econ. Model. 2008, 25, 83-92. [CrossRef]

10. Chaban, M. Cointegration analysis with structural breaks and deterministic trends: An application to the Canadian dollar. Appl. Econ. 2010, 42, 3023-3037. [CrossRef]

11. Zivot, E.; Andrews, D.W.K. Further Evidence on the Great Crash, the Oil-Price Shock, and the Unit-Root Hypothesis. J. Bus. Econ. Stat. 1992, 10, 251-270. [CrossRef]

12. Gregory, A.W.; Hansen, B.E. Residual-based tests for cointegration in models with regime shifts. J. Econom. 1996, 70, 99-126. [CrossRef]

13. Bahmani-Oskooee, M.; Domac, I. Turkish stock price and the value of Turkish Lira. Can. J. Dev. Stud. 1997, 18, 139-150. [CrossRef]

14. Kasman, S. The relationship between exchange rates and stock prices: A causality analysis. J. Soc. Sci. Inst. 2003, 5, 70-79.

15. Sevuktekin, M.; Nargelecekenler, M. Determining of the dynamic relationship between IMKB and exchange rates in Turkey. In Proceedings of the 8th Econometrics and Statistics Congress of Turkey, Inonu University, Malatya, Turkey, 24-25 May 2007.

16. Pekkaya, M.; Bayramoglu, M.F. Causality test between exchange rate and stock prices: An analysis on USD/YTL, ISE 100 and S\&P 500. J. MUFAD 2008, 38, 163-176.

17. Aydemir, O.; Demirhan, E. The relationship between stock prices and exchange rates evidence from Turkey. Int. Res. J. Financ. Econ. 2009, 23, 207-215.

18. Rjoub, H. Stock price and exchange rate dynamics: Evidence from emerging markets. Afr. J. Bus. Manag. 2012, 6, 4728-4733.

19. Pesaran, M.H.; Shin, Y.; Smith, R.J. Bound testing approaches to the analysis of level relationships. J. Appl. Econom. 2001, 16, 289-326. [CrossRef]

20. Bayer, C.; Hanck, C. Combining non-cointegration tests. J. Time Ser. Anal. 2013, 34, 83-95. [CrossRef]

21. Dornbusch, R.; Fisher, S. Exchange rates and the current account. Am. Econ. Rev. 1980, 70, 960-971.

22. Gavin, M. The stock market and exchange rate dynamics. J. Int. Money Financ. 1989, 38, 1-34. [CrossRef]

23. International Monetary Fund (2016), International Financial Statistics (IFS). Available online: http: / / data. imf.org (accessed on 7 November 2016).

24. Daniels, J.P.; Vanhoose, D.D. International Monetary and Financial Economics, 3rd ed.; Thomson South-Western: Chicago, IL, USA, 2005.

25. Perron, P. The great crash, the oil price shock, and the unit root hypothesis. Econometrica 1989, 57, $1361-1401$. [CrossRef]

26. Perron, P.; Vogelsang, T.J. Nonstationarity and Level Shifts with an Application to Purchasing Power Parity. J. Bus. Econ. Stat. 1992, 10, 301-320. [CrossRef]

27. Clemente, J.; Montañés, A.; Reyes, M. Testing for a unit root in variables with a double change in the mean. Econ. Lett. 1998, 59, 175-182. [CrossRef]

28. Engle, R.F.; Granger, C.W.J. Co-Integration and Error Correction: Representation, Estimation and Testing. Econometrica 1987, 55, 251-276. [CrossRef]

29. Johansen, S. Statistical analysis of cointegration vectors. J. Econ. Dyn. Control 1988, 12, 231-254. [CrossRef]

30. Boswijk, H.P. Testing for an unstable root in conditional and structural error correction models. J. Econ. 1994, 63, 37-60. [CrossRef]

31. Banerjee, A.; Dolado, J.; Mestre, R. Error-correction mechanism test for cointegration in a single-equation framework. J. Time Ser. Anal. 1998, 19, 267-283. [CrossRef]

(C) 2017 by the author. Licensee MDPI, Basel, Switzerland. This article is an open access article distributed under the terms and conditions of the Creative Commons Attribution (CC BY) license (http:/ / creativecommons.org/licenses/by/4.0/). 